\title{
Article \\ Heavy Metal Assessments of Soil Samples from a High Natural Background Radiation Area, Indonesia
}

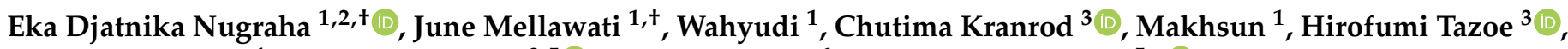 \\ Haeranah Ahmad ${ }^{4}$, Masahiro Hosoda ${ }^{2,5}\left(\mathbb{D}\right.$, Naofumi Akata ${ }^{6}$ and Shinji Tokonami ${ }^{5, *}$ (i)
}

1 Research Centre for Technology of Radiation Safety and Metrology, The National Research and Innovation Agency of Indonesia (OR TN-BRIN), Jakarta 12440, Indonesia; eka.dj.n@batan.go.id (E.D.N.);

june_mellawati@batan.go.id (J.M.); wah_yudi@batan.go.id (W.); makhsun@batan.go.id (M.)

2 Department of Radiation Science, Graduate School of Health Sciences, Hirosaki University, Hirosaki 036-8560, Japan; m_hosoda@hirosaki-u.ac.jp

3 Department of International Cooperation and Collaborative Research, Institute of Radiation Emergency Medicine, Hirosaki University, Hirosaki 036-8560, Japan; kranrodc@hirosaki-u.ac.jp (C.K.); tazoe@hirosaki-u.ac.jp (H.T.)

4 Department of Environmental Health, Health Polytechnic of Mamuju, Mamuju 91511, Indonesia; haeranahahmad@poltekkesmamuju.ac.id

5 Department of Radiation Measurement and Physical Dosimetry, Institute of Radiation Emergency Medicine, Hirosaki University, Hirosaki 036-8560, Japan

6 Department of Radiochemistry and Radioecology, Institute of Radiation Emergency Medicine, Hirosaki University, Hirosaki 036-8560, Japan; akata@hirosaki-u.ac.jp

* Correspondence: tokonami@hirosaki-u.ac.jp; Tel.: +81-172-39-5404

+ These authors contributed equally to this work.

check for updates

Citation: Nugraha, E.D.; Mellawati, J.; Wahyudi; Kranrod, C.; Makhsun; Tazoe, H.; Ahmad, H.; Hosoda, M.; Akata, N.; Tokonami, S. Heavy Metal Assessments of Soil Samples from a High Natural Background Radiation Area, Indonesia. Toxics 2022, 10, 39. https://doi.org/10.3390/ toxics10010039

Academic Editor: Lucica Barbes

Received: 31 December 2021

Accepted: 13 January 2022

Published: 15 January 2022

Publisher's Note: MDPI stays neutral with regard to jurisdictional claims in published maps and institutional affiliations.

Copyright: (C) 2022 by the authors. Licensee MDPI, Basel, Switzerland. This article is an open access article distributed under the terms and conditions of the Creative Commons Attribution (CC BY) license (https:// creativecommons.org/licenses/by/ $4.0 /)$.

\begin{abstract}
Mamuju, Indonesia, is an area with high natural background radiation. This study assesses heavy metal content in soil samples from this area to determine the level of public and environmental hazard it presents. This study analyzes natural radionuclide elements using high purity germanium (HPGe) gamma spectrometry and performs heavy metals analysis using a flame atomic absorption spectrometry (FAAS). Moreover, pollution indices and descriptive analyses were used to assess heavy metal contamination in the environment and the correlation between heavy metals and radionuclides. The results demonstrate that soil samples in several areas of Mamuju contain a high concentration of the natural radionuclides ${ }^{226} \mathrm{Ra}$ and ${ }^{232} \mathrm{Th}$, and that heavy metal concentrations in the soil decrease in the sequence $\mathrm{Zn}>\mathrm{Pb}>\mathrm{Cr}>\mathrm{Cu}>\mathrm{Ni}>\mathrm{Cd}$. This study revealed that soil samples from Mamuju are moderately contaminated. There was a strong positive relationship between ${ }^{226} \mathrm{Ra},{ }^{232} \mathrm{Th}$, ambient dose equivalent rate, and $\mathrm{Pb}$. Ecological risk index (RI) and cumulative pollution index (IPI) values in Mamuju are 2.05 and 125, respectively, which are possible hazards to human health as a result. $\mathrm{Pb}$ concentration in the Mamuju soil samples ranged from 109 to $744 \mathrm{mg} \mathrm{kg}^{-1}$, exceeding the worldwide average of $27 \mathrm{mg} \mathrm{kg}^{-1}$.
\end{abstract}

Keywords: toxic; lead; natural radiation

\section{Introduction}

Heavy metals are widely distributed in the environment and are often associated with pollution, contamination, and toxicity due to non-bio-degradable and persistence in nature $[1,2]$. In the environment, there are both natural and anthropogenic sources of heavy metals [1]. The main natural source is geological degradation, such as rock weathering or thermal springs. The anthropogenic sources come from sewage sludge, fossil fuel combustion, industrial processes, and organic and inorganic fertilizers [3].

Recently, heavy metals in the environment have increased beyond acceptable limits through development activities, including industry and agriculture. These heavy metals can be toxic and accumulate in the soft tissues of animals, plants, and even humans when 
they enter the body through food, water, air, or skin. Soil is often a repository of heavy metals because soil particles, such as clay and humus, have a charge that helps metal cations bind to the soil, thereby preventing their release, even temporarily [4]. Heavy metal toxicity can cause several diseases that attack almost all vital organ functions [5]. Some heavy metals that can cause health include copper $(\mathrm{Cu})$, chromium $(\mathrm{Cr})$, cadmium $(\mathrm{Cd})$, lead $(\mathrm{Pb})$, nickel $(\mathrm{Ni})$, and zinc $(\mathrm{Zn})$.

$\mathrm{Pb}$ is a harmful environmental pollutant with high toxic effects on many body organs. $\mathrm{Pb}$ is absorbed from the respiratory and digestive systems. Due to immune modulation, oxidative, and inflammatory mechanisms, $\mathrm{Pb}$ exposure can induce neurological, respiratory, urinary, and cardiovascular disorders. Cr is found in the Earth's crust and industrial processes. The main route of $\mathrm{Cr}$ exposure is via ingestion and can cause various diseases, such as renal, neurological, and several cancers, including lungs, bladder, kidneys, thyroid, testicles, and bone. $\mathrm{Cd}$, although rare, occurs naturally in soil. A high concentration of $\mathrm{Cd}$ in the soil can occur following industrial activities, with the main exposure route being ingestion. Health effects due to this heavy metal are degenerative bone diseases, kidney failure, and lungs diseases. $\mathrm{Zn}$ and $\mathrm{Ni}$ are essential heavy metals in the human body. However, exposure to extreme elements can be harmful to respiratory diseases. $\mathrm{Cu}$, as well as Cr, is found in the Earth's crust. The health effect of this heavy metal concerns abdominal disorders and metabolic activity abnormalities [5-8].

Several studies have also discussed heavy metal pollution in areas with high levels of natural radionuclide elements in the soil, such as areas around uranium mines with high background radiation [9-11]. As with heavy metals, high concentrations of radionuclides in the soil in an area can cause radiation-induced diseases, such as cancer and non-cancer diseases. Uranium exploration activities employing poor residue management techniques adversely affect the environment. Significant concentrations of radionuclides in the soil and water are generally accompanied by significant heavy metal contents [12].

Mamuju, Indonesia has a relatively high average radiation dose rate due to its high natural background radiation level [13-16]. Mapping of radiation dose rates at several locations in the Mamuju area was conducted by the Research Center for Radiation and Metrology Technology (PRTKMR) of the National Research and Innovation Agency of Indonesia (OR TN-BRIN) and Hirosaki University, Japan. A geometric mean of $613 \mathrm{nSv} \mathrm{h}^{-1}$ with a range of 200 to $2300 \mathrm{nSv} \mathrm{h}^{-1}$ was found [13].

A previous study has found that Mamuju has a unique geological condition, with 15 types of rock with different mineral contents, 11 types of class $C$ minerals, 6 types of Class B minerals, and 5 types of class A minerals found in this area [14]. Volcanic rocks with ultrapotassic affinity and andesitic basaltic types are grouped in the Adang volcanic rock area, formed on the active continental margin (ACM) with the microcontinental crust of the SW Sulawesi block [17,18]. Rosianna et al. (2020) measured radioactivity in samples of breccia rock, tephra-phonolite, phonolite, phono-tephrite, and trachyte in several areas of Mamuju using a high-purity germanium detector (HPGe) with an activity concentration of ${ }^{238} \mathrm{U}$ from 539 to $128,699 \mathrm{~Bq} \mathrm{~kg}^{-1}$ and ${ }^{232} \mathrm{Th}$ from 471 to $288,639 \mathrm{~Bq} \mathrm{~kg}^{-1}$ [19]. According to the mineralization, the main minerals in Mamuju are davidite and thorianite that contain heavy metals, uranium, and thorium [20]. Moreover, secondary minerals are gummite and autunite [17].

This study assesses heavy metal levels in soil samples taken in Mamuju in order to determine the possibility of environmental and public hazards resulting from heavy metals in this area. Heavy metal pollution in the soil can have harmful effects on groundwater, agricultural production, food safety, and human health because the soil is the most important ecosystem for human survival and development. Most people living in Mamuju are farmers, and their daily life in the area is, therefore, heavily dependent on nature. Most residents mainly consume locally grown food from traditional markets. Therefore, the determination of the heavy metal content in the local soil is fundamental to the identification, monitoring, and assessment of potential sources of pollution in the area [6,9]. 
This paper describes the first approach to assess heavy metal contamination in Mamuju. Previous studies on Mamuju examined specific areas rather than the region as a whole, and had limited scope, focusing purely on natural radioactivity, radiation dose assessment, and radioactive mineral exploration [13-15,19,21].

\section{Materials and Methods}

\subsection{Study Area}

Mamuju is located on the western edge of Sulawesi Island, between Mamuju Bay to the north and Labani Bay to the south. The topography of the Mamuju area consists of a western coastal area and an eastern mountainous area [14,22]. The landscape is still natural in that there has been no mining activity. At $62 \%$ of the population, the majority of Mamuju residents are farmers; the primary agricultural product is cacao, an exported commodity [13]. Due to these circumstances, we assessed several heavy metals in soil samples, such as $\mathrm{Cu}, \mathrm{Cr}, \mathrm{Cd}, \mathrm{Pb}, \mathrm{Ni}$, and $\mathrm{Zn}$, which might affect the health of the Mamuju residents based on their activities and geological conditions.

Soil samples were obtained from the sub-districts of Mamaju city (Binanga Village, Tama Sapi, Mamuyu Village, So'do, Rimuku, and Karema), Tapalang sub-district (Takandeang Village, Tabanga-banga, and Palada), and Northern Botteng Village. Figure 1 shows a map of these locations.

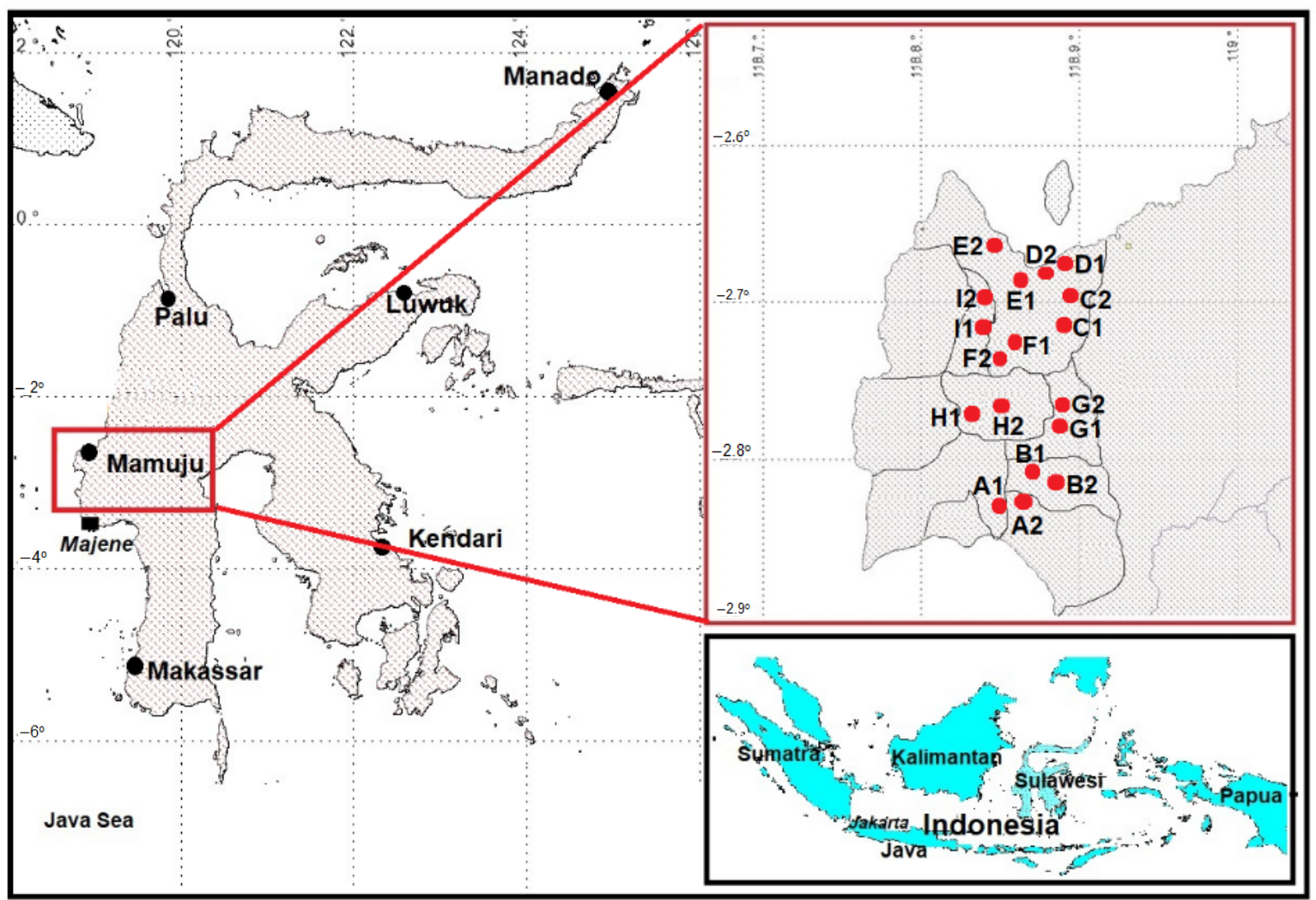

Figure 1. Study area. The red dots represent the sample sites used in this study, and the black dots represent the capital cities of Indonesian provinces.

\subsection{Sampling and Preparation}

Soil samples were collected from 18 different locations in Mamuju. Each sample consisted of $1 \mathrm{~kg}$ of soil extracted at a depth of 5-20 cm from the soil surface using a trowel. Then, soil samples were stored in polymer bags. In the laboratory, the extraneous plant material, rocks, gravel, and roots were removed from the soil samples, then dried in an oven at $105^{\circ} \mathrm{C}$ for $24 \mathrm{~h}$ to remove the moisture content. The soil samples were then 
crushed by hand, sieved using a 50-60 mesh sieve, and separated into two parts for natural radionuclide element analysis and heavy metal analysis.

\subsection{Identification of Heavy Metal Elements}

The samples after preparation were heated in a furnace at $400{ }^{\circ} \mathrm{C}$ for $2 \mathrm{~h}$ to remove organic matters. An aqua-regia extraction method was then used to determine the total metal content of each sample. This method consists of the partial digestion (by $\mathrm{HNO}_{3}-$ $\mathrm{HCl}$ ) of $1 \mathrm{~g}$ of the soil sample for $2 \mathrm{~h}$ at $90{ }^{\circ} \mathrm{C}$. Afterward, the sample was diluted to $100 \mathrm{~mL}$ with de-ionized water, left for $3 \mathrm{~h}$, and then filtered [23,24]. All chemicals and standard solutions were purchased from Merck (Darmstadt, Germany). A flame atomic absorption spectrometer (ContrAA 300, Analytic, Jena, Germany; 'FAAS' hereafter) was used to carry out heavy metal element analysis. The FAAS was calibrated with the relevant Analytic Jena FAAS grade standards. All results were measured in triplicate, and average values were calculated. Moreover, we measured the certified reference material (CRM) OREAS 465 (Tanzania-Mantra Resources Nyota Prospect) to obtain accurate and precise measurement. Obtained values are in good agreement with the certificate of CRM. The minimum detection concentrations (MDCs) of $\mathrm{Cu}, \mathrm{Cr}, \mathrm{Cd}, \mathrm{Pb}, \mathrm{Ni}$, and $\mathrm{Zn}$ were $0.15,0.41$, $0.14,1.5$, and $0.22 \mathrm{mg} \mathrm{kg}^{-1}$, respectively.

\subsection{Radioactivity Measurement}

A high purity germanium (HPGe) detector gamma spectrometer (Ortec, Oak Ridge, TN, USA) was used to measure the radioactivity of the sample. Each approximately $1 \mathrm{~kg}$ sample was weighed and sealed in a standard Marinelli container, and placed for approximately 30 days before further gamma spectrometer measurement to allow the decay products to reach secular equilibrium. The counting time was approximately 80,000 s. The peak energy values of 351 and $609 \mathrm{keV}$ were used to calculate ${ }^{238} \mathrm{U}$ and ${ }^{226} \mathrm{Ra}$, respectively. The energy peaks of 238,581, and $911 \mathrm{keV}$ were used for ${ }^{232} \mathrm{Th}$, and the single peak of $1460 \mathrm{keV}$ was used for ${ }^{40} \mathrm{~K}$. The MDCs of ${ }^{226} \mathrm{Ra},{ }^{232} \mathrm{Th}$, and ${ }^{40} \mathrm{~K}$ used for this measurement were 0.0052, 0.0052, 0.0034, and $0.0146 \mathrm{~Bq} \mathrm{~kg}^{-1}$, respectively. Equation (1) is used to calculate the radioactivity concentration from these measurements:

$$
A=\frac{N}{E Y W f_{c}}
$$

where $E$ is counting efficiency, $Y$ is energy yield, $N$ is net count per second, $W$ is sample weight $(\mathrm{kg})$, and $F_{c}$ is the correction factor (including recovery factor, attenuation factor, summing in, summing out, growth factor and decay factor) $[13,19,25]$.

\subsection{Assessment of Environmental Heavy Metal Contamination}

This study used three assessment tools to determine the level of contamination of a research area. Pollution indices also involve some heavy metal measurement and geological background data of an area. Geochemical index (I-Geo) aims to determine metal contamination in soil by comparing current concentrations with preindustrial levels. The pollution index (PI) aims to determine metal contamination in soil by comparing current concentration with the regional background. Moreover, ecological risk (RI) and the potential ecological risk of each heavy metal $\left(E_{i}\right)$ are aimed to assess the level of contamination in soil based on the toxicity of heavy metals and environmental response.

\subsubsection{Geo-Accumulation Index (I-Geo)}

The geo-accumulation index (I-Geo) is a quantitative indicator to measure the degree of soil pollution by heavy metals [26]. I-Geo is expressed by the following equation [27]:

$$
\mathrm{I}-\mathrm{Geo}=\log 2\left(\frac{\mathrm{Cn}}{1.5 B n}\right)
$$


where $B n$ is the background value in the upper continental crust and $C n$ is the total of heavy metal contents [28], and 1.5 is the background matrix correction factor. The I-Geo was categorized into seven classes: uncontaminated (I-Geo $\leq 0$ ), uncontaminated to fairly contaminated $(0<\mathrm{I}-\mathrm{Geo} \leq 1)$, fairly contaminated $(1<\mathrm{I}-\mathrm{Geo} \leq 2)$, fairly contaminated to heavily contaminated $(2<\mathrm{I}-\mathrm{Geo} \leq 3)$, heavily contaminated $(3<\mathrm{I}-\mathrm{Geo} \leq 4)$, heavily contaminated to extraordinarily contaminated $(4<\mathrm{I}-\mathrm{Geo} \leq 5)$, and extraordinarily contaminated $(\mathrm{I}-\mathrm{Geo} \geq 5)[29,30]$.

\subsubsection{Pollution Index (PI)}

The pollution index (PI) of each metal is the ratio of the heavy metal content in the sample to the regional background and calculated according to the following equation:

$$
\mathrm{PI}=\frac{C n}{B n}
$$

where $C n$ is the heavy metal content, $B n$ is the regional background heavy metal content, and PI is the pollution index. The baseline data of regional background defined by Reimann and Caritat [28] are $\mathrm{Pb}=14.8 \mathrm{ppm}, \mathrm{Zn}=80 \mathrm{ppm}, \mathrm{Cu}=75 \mathrm{ppm}$, and $\mathrm{Cd}=0.15 \mathrm{ppm}$. The PI classified into three classifications as low (PI $\leq 1)$, middle $(1<\mathrm{PI} \leq 3)$, or high (PI $>3)$. The integrated pollution index (IPI) is the mean value for all PI for all considered heavy metals. The IPI are classified as either low (IPI $\leq 1.0)$, moderate $(1.0<\mathrm{IPI} \leq 2.0)$, high $(2.0<\mathrm{IPI} \leq 5.0)$, or extremely high contamination (IPI $>5)[23,30]$.

\subsubsection{Ecological Risk Index (RI)}

The ecological risk index (RI) consisted of the sum of individual heavy metals $\left(E_{i}\right)$ and was used to evaluate the potential ecological risk factor of soil pollution by assessing the heavy metals [31]. It represents the biological sensitivity to toxic substances and demonstrates the potential ecological risk caused by heavy metal contamination [32]. The RI was calculated with the following equation:

$$
\begin{gathered}
\mathrm{RI}=\sum E_{i} \\
E_{i}=T_{i} \cdot f_{i}=T_{i} \frac{C_{i}}{B_{i}}
\end{gathered}
$$

where $T_{i}$ is the toxic response factor for heavy metal, and $f_{i}$ is the ratio of the measured concentration $\left(C_{i}\right)$ to the background concentration $\left(B_{i}\right)$ of metal in the soil. The $T_{i}$ values for the heavy metals studied were 5 for $\mathrm{Pb}$ and $\mathrm{Cu}, 1$ for $\mathrm{Zn}$, and 30 for $\mathrm{Cd}$. The potential ecological risk of each heavy metal $\left(E_{i}\right)$ was classified into five categories as either low $\left(E_{i}<40\right)$, fairly $\left(40 \leq E_{i}<80\right)$, considerable $\left(80 \leq E_{i}<160\right)$, high $\left(160 \leq E_{i}<320\right)$, or very high $\left(E_{i}>320\right)$. Tang et al. (2013), categorized the RI into four classes: low $(\mathrm{RI}<150)$, moderate $(150<\mathrm{RI} \leq 300)$, high $(300<\mathrm{RI} \leq 600)$, and very high $(\mathrm{RI}>600)$ [30].

\subsection{Statistical Analysis and Map Creation}

We used MAPINFO PROFESSIONAL (version 10.5, Precisely, Burlington, MA, USA) to create maps, and ORIGIN PRO 2021 (student version, OriginLab Corp, Northampton, MA, USA) to perform bivariate analysis in order to find significant relationships between the distribution coefficients of radionuclides and heavy metals [19,33]. We conducted a Pearson correlation analysis and calculated the values of Pearson correlation coefficients with a two-tailed significance test ( $p$-value at $0.05,0.01$ and 0.001 ). The equation below expresses the Pearson correlation coefficients:

$$
r=\frac{\sum_{i=1}^{n}\left(x_{i}-\bar{x}\right)\left(y_{i}-\bar{y}\right)}{\sqrt{\sum_{i=1}^{n}\left(x_{i}-\bar{x}\right)^{2}} \sqrt{\sum_{i=1}^{n}\left(y_{i}-\bar{y}\right)^{2}}}
$$

where $n$ is the sample size, $x_{i}$ and $y_{i}$ are the individual sample points indexed, and $\bar{x}, \bar{y}$ is the sample mean. 


\section{Results}

\subsection{Radioactivity and Heavy Metal Elements in the Soil Sample}

The activity concentration of ${ }^{226} \mathrm{Ra},{ }^{232} \mathrm{Th}$, and ${ }^{40} \mathrm{~K}$ in surface soil samples from Mamuju is presented in Table 1 . The activity concentration of ${ }^{226} \mathrm{Ra}$ varied from 232 to $2761 \mathrm{~Bq} \mathrm{~kg}^{-1}$, with an average of $784 \mathrm{~Bq} \mathrm{~kg}^{-1}$. The activity concentration of ${ }^{232} \mathrm{Th}$ varied from 424 to $3310 \mathrm{~Bq} \mathrm{~kg}{ }^{-1}$, with an average of $1008 \mathrm{~Bq} \mathrm{~kg}^{-1}$. The activity concentration of ${ }^{40} \mathrm{~K}$ ranged from 203 to $1655 \mathrm{~Bq} \mathrm{~kg}^{-1}$, with an average $770 \mathrm{~Bq} \mathrm{~kg}^{-1}$.

Table 1. The descriptive statistics of ambient dose equivalent rate, natural radionuclides, and heavy metals in a soil sample from Mamuju.

\begin{tabular}{|c|c|c|c|c|c|c|}
\hline Measurement & Average & Min & Max & SD & Skewness & Kurtosis \\
\hline $\begin{array}{l}\text { Ambient dose equivalent } \\
\text { rate }\left(n S v h^{-1}\right)\end{array}$ & $699 \pm 65$ & $235 \pm 20$ & $2260 \pm 219$ & 634 & 1.70 & 2.12 \\
\hline${ }^{226} \mathrm{Ra}\left(\mathrm{Bq} \mathrm{kg}^{-1}\right)$ & $784 \pm 40$ & $232 \pm 12$ & $2761 \pm 138$ & 707 & 2.01 & 3.57 \\
\hline${ }^{232} \mathrm{Th}\left(\mathrm{Bq} \mathrm{kg}-{ }^{1}\right)$ & $1008 \pm 45$ & $424 \pm 22$ & $3310 \pm 166$ & 954 & 1.80 & 1.74 \\
\hline${ }^{40} \mathrm{~K}\left(\mathrm{~Bq} \mathrm{~kg}^{-1}\right)$ & $770 \pm 46$ & $203 \pm 16$ & $1655 \pm 99$ & 506 & 0.36 & -1.25 \\
\hline $\mathrm{Cu}\left(\mathrm{mg} \mathrm{kg}^{-1}\right)$ & $71 \pm 4$ & $23 \pm 1$ & $145 \pm 6$ & 44 & 0.52 & -1.53 \\
\hline $\mathrm{Cr}\left(\mathrm{mg} \mathrm{kg}^{-1}\right)$ & $84 \pm 4$ & $11 \pm 0.55$ & $293 \pm 12$ & 72 & 2.17 & 4.69 \\
\hline $\mathrm{Cd}\left(\mathrm{mg} \mathrm{kg}^{-1}\right)$ & $0.69 \pm 0.14$ & $0.40 \pm 0.14$ & $1.40 \pm 0.14$ & 0.35 & 1.45 & 0.91 \\
\hline $\mathrm{Pb}\left(\mathrm{mg} \mathrm{kg}^{-1}\right)$ & $303 \pm 18$ & $109 \pm 7$ & $744 \pm 37$ & 204 & 0.98 & -0.27 \\
\hline $\mathrm{Ni}\left(\mathrm{mg} \mathrm{kg}^{-1}\right)$ & $41 \pm 2$ & $4 \pm 1.50$ & $69 \pm 3$ & 20 & -0.68 & -0.39 \\
\hline $\mathrm{Zn}\left(\mathrm{mg} \mathrm{kg}^{-1}\right)$ & $304 \pm 15$ & $175 \pm 9$ & $392 \pm 20$ & 62 & -0.77 & 0.12 \\
\hline
\end{tabular}

The concentrations of heavy metal in soil samples from the Mamuju area presented in Table 1 varied from 23 to $145 \mathrm{mg} \mathrm{kg}^{-1}(\mathrm{Cu}), 11$ to $293 \mathrm{mg} \mathrm{kg}^{-1}(\mathrm{Cr}), 0.40$ to $1.40 \mathrm{mg} \mathrm{kg}^{-1}$ (Cd), 109 to $744 \mathrm{mg} \mathrm{kg}^{-1}(\mathrm{~Pb}), 4$ to $69 \mathrm{mg} \mathrm{kg}^{-1}$ (Ni), and 175 to $392 \mathrm{mg} \mathrm{kg}^{-1}$ (Zn).

\subsection{Assessment of Heavy Metal Pollution}

The I-Geo, EI, RI, PI, and IPI pollution indices were used to identify heavy metal concentrations of environmental concern in the Mamuju soil samples. These indices numerically describe pollution levels in soils and can be used to calculate the exchangeable soil fraction by representing the real bio-available fraction. The pollution indices of the Mamuju samples are shown in Table 2.

The I-Geo values found for $\mathrm{Cu}, \mathrm{Cr}, \mathrm{Cd}, \mathrm{Ni}$, and $\mathrm{Zn}$ show that the samples are within the uncontaminated to fairly contaminated category with an I-geo value of $<1$, except for the $\mathrm{Pb}$ value which has an I-Geo average of 4.11 and a range of $1.48-10$. The average I-Geo score for $\mathrm{Pb}$ in the Mamuju soil samples is within the heavily contaminated to extraordinary contaminated category $(4<\mathrm{I}-\mathrm{Geo} \leq 5)$.

The PI values, i.e., the ratio of heavy metal content in the samples to the regional background heavy metal content were $<1$ for $\mathrm{Cu}, \mathrm{Cr}$, and $\mathrm{Ni}$, and were therefore within the low contamination category. The PI values of $\mathrm{Cd}, \mathrm{Pb}$, and $\mathrm{Zn}$ were $>3$, and were therefore in the high contamination category. The IPI value for the Mamuju soil samples was 2.05 with a range from 1.16 to 3.06, and was therefore within the moderate contamination category.

The EI value is used to evaluate the potential ecological risk of heavy metal soil pollution. EI values for $\mathrm{Cu}, \mathrm{Cr}, \mathrm{Cd}, \mathrm{Ni}$, and $\mathrm{Zn}$ in the samples were all $<40$, and were therefore within the low contamination category. The average EI value for $\mathrm{Pb}$ was 102 with a range of 37-251, which is within the medium contamination category $\left(80 \leq E_{i}<160\right)$. The RI value is used to evaluate the combined ecological risk of heavy metal soil pollution. The RI values of the samples ranged from 53 to 277, with an average of 125, and were therefore mainly within the low contamination category with some areas included in the moderate contamination category. 
Table 2. Heavy metal pollution indices in Mamuju.

\begin{tabular}{|c|c|c|c|c|c|c|c|}
\hline \multirow{2}{*}{ Pollution Indices } & \multirow{2}{*}{ Descriptive Statistic } & \multicolumn{6}{|c|}{ Heavy Metal } \\
\hline & & $\mathrm{Cu}$ & $\mathrm{Cr}$ & $\mathrm{Cd}$ & $\mathbf{P b}$ & $\mathbf{N i}$ & Zn \\
\hline \multirow{6}{*}{ I-Geo } & Average & 0.19 & 0.17 & 0.92 & 4.11 & 0.11 & 0.76 \\
\hline & $\min$ & 0.06 & 0.02 & 0.54 & 1.48 & 0.01 & 0.44 \\
\hline & $\max$ & 0.39 & 0.59 & 1.87 & 10 & 0.18 & 0.98 \\
\hline & SD & 0.12 & 0.14 & 0.47 & 2.76 & 0.05 & 0.15 \\
\hline & Skewness & 0.52 & 2.17 & 1.45 & 0.98 & -0.68 & -0.77 \\
\hline & Kurtosis & -1.53 & 4.69 & 0.91 & -0.27 & -0.39 & 0.12 \\
\hline \multirow{6}{*}{ EI } & Average & 4.76 & 1.68 & 9.19 & 102 & 2.71 & 3.80 \\
\hline & $\min$ & 1.53 & 0.22 & 5.33 & 37 & 0.27 & 2.19 \\
\hline & $\max$ & 9.67 & 5.86 & 19 & 251 & 4.60 & 4.90 \\
\hline & SD & 2.97 & 1.44 & 4.66 & 69 & 1.31 & 0.77 \\
\hline & Skewness & 0.52 & 2.17 & 1.45 & 0.98 & -0.68 & -0.77 \\
\hline & Kurtosis & -1.53 & 4.69 & 0.91 & -0.27 & -0.39 & 0.12 \\
\hline \multirow{6}{*}{ PI } & Average & 0.95 & 0.84 & 4.59 & 20 & 0.54 & 3.80 \\
\hline & $\min$ & 0.31 & 0.11 & 2.67 & 7.36 & 0.05 & 2.19 \\
\hline & $\max$ & 1.93 & 2.93 & 9.33 & 50 & 0.92 & 4.90 \\
\hline & SD & 0.59 & 0.72 & 2.33 & 14 & 0.26 & 0.77 \\
\hline & Skewness & 0.52 & 2.17 & 1.45 & 0.98 & -0.68 & -0.77 \\
\hline & Kurtosis & -1.53 & 4.69 & 0.91 & -0.27 & -0.39 & 0.12 \\
\hline \multirow{6}{*}{ RI } & Average & \multicolumn{6}{|c|}{125} \\
\hline & $\min$ & \multicolumn{6}{|c|}{53} \\
\hline & $\max$ & \multicolumn{6}{|c|}{277} \\
\hline & $\mathrm{SD}$ & \multicolumn{6}{|c|}{72} \\
\hline & Skewness & \multicolumn{6}{|c|}{0.89} \\
\hline & Kurtosis & \multicolumn{6}{|c|}{-0.46} \\
\hline \multirow{6}{*}{ IPI } & Average & \multicolumn{6}{|c|}{2.05} \\
\hline & $\min$ & \multicolumn{6}{|c|}{1.16} \\
\hline & $\max$ & \multicolumn{6}{|c|}{3.06} \\
\hline & SD & \multicolumn{6}{|c|}{0.66} \\
\hline & Skewness & \multicolumn{6}{|c|}{0.49} \\
\hline & Kurtosis & \multicolumn{6}{|c|}{-1.39} \\
\hline
\end{tabular}

\section{Discussion}

In general, Mamuju soil samples were indicated to have a level of environmental radioactivity that is above the worldwide average. Worldwide average activity concentrations of ${ }^{40} \mathrm{~K},{ }^{226} \mathrm{Ra}$, and ${ }^{232} \mathrm{Th}$ were reported as $412 \mathrm{~Bq} \mathrm{~kg}^{-1}, 33 \mathrm{~Bq} \mathrm{~kg}^{-1}$, and $45 \mathrm{~Bq} \mathrm{~kg}$, respectively [34]. The study result is similar to a previous study conducted by Nugraha et al. (2021), which measured radioactivity in the soil at different sampling points using an HPGe detector. The average activity concentrations of ${ }^{238} \mathrm{U},{ }^{232} \mathrm{Th}$, and ${ }^{40} \mathrm{~K}$ measured by Nugraha et al. (2021) were $1387 \mathrm{~Bq} \mathrm{~kg}{ }^{-1}, 1468 \mathrm{~Bq} \mathrm{~kg}^{-1}$, and $301 \mathrm{~Bq} \mathrm{~kg}^{-1}$, respectively [13]. In addition, Nurokhim et al. reported that natural radioactivity in soil samples in the Botteng Utara (Northern Botteng) village had an average concentration of $1042 \mathrm{~Bq} \mathrm{~kg}^{-1}$ for ${ }^{226} \mathrm{Ra}, 1756 \mathrm{~Bq} \mathrm{~kg}{ }^{-1}$ for ${ }^{232} \mathrm{Th}$, and $\mathrm{Bq} \mathrm{kg}{ }^{-1}$ for ${ }^{40} \mathrm{~K}$ [35].

Uranium and thorium are terrestrial naturally occurring radioactive materials (NORMs) which form in the Earth's crust. ${ }^{226} \mathrm{Ra}$ is a decay product of uranium with a half-life of 1600 years. ${ }^{226} \mathrm{Ra}$ contained in the soil can potentially accumulate into plants or animals which are consumed by people. Geological conditions strongly influence natural radionuclide activities, and rocks of the alkali basalt group (phonolite, phonotepite, and monolith) found in the Mamuju area (in sub-districts Botteng and Takandeang) are radioactive. Extrusive mafic stone basalt is the most extensive of all frozen rocks, and comprises more than $90 \%$ of all volcanic rocks [19]. Moreover, the high concentration of uranium and thorium in the soil, apart from exposing plants, animals, and humans through inhalation and ingestion, can also contribute to gamma radiation exposure. The ambient dose equivalent rate in 
Mamuju ranged from 235 to $2260 \mathrm{nSv} \mathrm{h}{ }^{-1}$. A similar value was reported by Nugraha et al. (2021) with a geometric mean of $613 \mathrm{nSv} \mathrm{h}{ }^{-1}$ and a range of 200 to $2300 \mathrm{nSv} \mathrm{h}{ }^{-1}$, and Shilfa et al. (2021) reported an ambient dose equivalent rate in Northern Botteng which ranged from 420 to $1430 \mathrm{nSv} \mathrm{h}^{-1}[14,36]$.

The heavy metal concentrations in the soil decrease in the sequence $\mathrm{Zn}>\mathrm{Pb}>\mathrm{Cr}>\mathrm{Cu}>$ $\mathrm{Ni}>\mathrm{Cd}$. The $\mathrm{Pb}$ concentration in the Mamuju soil samples ranged from 109 to $744 \mathrm{mg} \mathrm{kg}^{-1}$, exceeding the worldwide average of $27 \mathrm{mg} \mathrm{kg}^{-1}$ [37]. Moreover, $\mathrm{Pb}$ concentrations in the Mamuju soil samples exceeded the thresholds for heavy metals in soil set by the World Health Organization (WHO), Indonesian Ministry of Environment, and the United States of America Environmental Protection Agency (US EPA), which are $0.1 \mathrm{mg} \mathrm{kg}^{-1}, 100 \mathrm{mg} \mathrm{kg}^{-1}$, and $200 \mathrm{mg} \mathrm{kg}^{-1}$, respectively [37-39].

Similar results with heavy metal assessment using pollution indices indicate a possibility that humans may be exposed to these pollutants. The lead value has an I-Geo average of 4.11 and a range of 1.48-10. The average I-Geo value for $\mathrm{Pb}$ in the Mamuju soil samples is within the heavily contaminated to extremely contaminated category $(4<\mathrm{I}-\mathrm{Geo} \leq 5)$. The highest values are in Botteng (I-Geo $=6)$, North Botteng $(\mathrm{I}-\mathrm{Geo}=7)$, and Takandeang $(\mathrm{I}-\mathrm{Geo}=10)$ areas. The PI values of $\mathrm{Cd}, \mathrm{Pb}$, and $\mathrm{Zn}$ were $>3$, and were therefore in the high contamination category. Although the PI values for $\mathrm{Cd}$ and $\mathrm{Zn}$ are high, these concentrations are still below the limits set by the Indonesian Ministry of Environment. The IPI value for the Mamuju soil samples of 2.05 was, therefore, within the medium contamination category. Moreover, the EI values for $\mathrm{Cu}, \mathrm{Cr}, \mathrm{Cd}, \mathrm{Ni}$, and $\mathrm{Zn}$ in the samples were within the low contamination category. However, the average EI value for $\mathrm{Pb}$ was 102 with a range of 37-251, which is within the medium contamination category $\left(80 \leq E_{i}<160\right)$ and the combined ecological risk of heavy metal soil pollution (RI) values of the samples ranged from 53 to 277, with an average of 125 .

This study reveals that Mamuju soil is categorized as moderately contaminated, especially in the case of $\mathrm{Pb}$ if the contaminated soil is utilized for agricultural activities. These levels of heavy metal accumulation in soils may increase the phyto-accumulation of these metals in crops grown on the soil. It is really well worth noting that even low levels of heavy metal pollutants can accumulate over time in exposed people and animals [37].

The high concentration of $\mathrm{Pb}$ in the soil can affect various things, especially public health. This is because the nature of $\mathrm{Pb}$ has high toxic effects on multiple organ problems. $\mathrm{Pb}$ can be absorbed into the human body through the respiratory and digestive systems. Exposure to high levels of $\mathrm{Pb}$ can cause anemia, kidney weakness, and brain damage. $\mathrm{Pb}$ can cross the placental barrier, which means that the exposure of pregnant women to it may also expose their unborn child. $\mathrm{Pb}$ can damage the nervous systems of developing babies [40,41]. Based on data from the Central Statistics Agency, Indonesia (2019), upper respiratory tract infections were the most common disease in Mamuju, with 21,070 cases. They are then followed by gastritis, hypertension, and diarrhea with 18,177 cases, 15,876 cases, and 8488 cases, respectively. Based on these data, it is necessary to carry out further thorough research to answer whether the case of Health in Mamuju is closely related to high levels of heavy metals and natural radionuclides. With these facts, Mamuju can be a prospective area for epidemiological studies to be carried out for both low-dose-rate radiation and heavy metal radiation.

Several studies of heavy metals in soils in several regions of the world include Toplica (Serbia), Severodvinsk (Russia), Bayanwula (China), Tong Liao (China), and Kerala (India). [1,4,42-44]. Toplica area, Serbia, a tourist city, has heavy metals dominated by arsenic (As; the average concentration $17 \mathrm{mg} \mathrm{kg}^{-1}$ ), $\mathrm{Cu}$, and Ni. Severodvinsk city is the largest industrial center for the navy in north-western Russia with concentrations of As (the average concentration $\left.12.6 \mathrm{mg} \mathrm{kg}^{-1}\right), \mathrm{Cd}$, and $\mathrm{Pb}$, which are higher than others. Bayanwula and Tongliao cities in China are uranium mining areas. The Tongliao area has very high $\mathrm{Cd}$, 7-8 times the average soil concentration in China, while the Bayanwula area has a higher concentration of $\mathrm{Pb}$ than other heavy metals. In Kerala, India, which is also a high natural background radiation area, the concentration of $\mathrm{Pb}$ was found to be higher than in other 
elements. Table 3 shows the comparison of heavy metal and radionuclide concentrations in the Mamuju area and several regions in the world.

Table 3. The comparison of heavy metal and radionuclide concentrations in the Mamuju area and several regions in the world.

\begin{tabular}{|c|c|c|c|c|c|c|c|c|c|c|}
\hline Area & $\begin{array}{c}{ }^{226} \mathrm{Ra} \\
\left(\mathrm{Bq} \mathrm{kg}^{-1}\right)\end{array}$ & $\begin{array}{c}{ }^{232} \mathrm{Th} \\
\left(\mathrm{Bq} \mathrm{kg}^{-1}\right)\end{array}$ & $\begin{array}{c}{ }^{40} \mathrm{~K} \\
\left(\mathrm{~Bq} \mathrm{~kg} \mathrm{~kg}^{-1}\right)\end{array}$ & $\begin{array}{c}\mathrm{Cu} \\
\left(\mathrm{mg} \mathrm{kg}^{-1}\right)\end{array}$ & $\begin{array}{c}\mathrm{Cr} \\
\left(\mathrm{mg} \mathrm{kg}^{-1}\right)\end{array}$ & $\begin{array}{c}\mathrm{Cd} \\
\left(\mathrm{mg} \mathrm{kg}^{-1}\right)\end{array}$ & $\begin{array}{c}\mathrm{Pb} \\
\left(\mathrm{mg} \mathrm{kg}^{-1}\right)\end{array}$ & $\begin{array}{c}\mathrm{Ni} \\
\left(\mathrm{mg} \mathrm{kg}^{-1}\right)\end{array}$ & $\begin{array}{c}\mathrm{Zn} \\
\left(\mathrm{mg} \mathrm{kg}^{-1}\right)\end{array}$ & Reference \\
\hline This Study & 784 & 1008 & 770 & 71 & 84 & 0.69 & 303 & 41 & 304 & This study \\
\hline Top Lica, Serbia & 30 & 37 & 492 & 40 & 100 & 0.12 & 47 & 118 & 111 & [1] \\
\hline $\begin{array}{l}\text { Severodvinsk, } \\
\text { Rusia }\end{array}$ & 12 & 9 & 191 & 8 & 20 & 0.19 & 10 & 10 & 25 & {$[44]$} \\
\hline Bayanwula, China & 25 & 29 & 923 & 5 & 15 & 0.01 & 74 & 5 & 118 & [43] \\
\hline Tong liao, China & 13 & 16 & 747 & 8 & - & 1.73 & 35 & - & 30 & [42] \\
\hline Kerala, India & 350 & 2825 & 180 & - & 116 & 0.26 & 83 & 36 & & {$[4,14]$} \\
\hline $\begin{array}{l}\text { Soil World } \\
\text { Average }\end{array}$ & 32 & 45 & 400 & 20 & 100 & 1.00 & 10 & 40 & 50 & {$[34,39]$} \\
\hline
\end{tabular}

\section{Correlation of Natural Radionuclides and Heavy Metals}

The correlations between heavy metals and natural radionuclides in soil samples were performed using the ORIGIN PRO 2021 (student version, OriginLab Corp, Northampton, MA, USA). The statistical significance of bivariate analysis is useful to find significant relationships between the distribution coefficients of radionuclides and heavy metals. The correlation coefficient results between radionuclides, ambient dose equivalent rates, and heavy metals in the soil samples are presented in Figure 2. There was a strong positive relationship ( $p \leq 0.001$ ) between ${ }^{226} \mathrm{Ra},{ }^{232} \mathrm{Th}$, ambient dose equivalent rate, $\mathrm{Pb}$, and $\mathrm{Cu}$ with correlation coefficients of $0.92\left({ }^{226} \mathrm{Ra}\right.$ and $\left.{ }^{232} \mathrm{Th}\right), 0.90\left({ }^{226} \mathrm{Ra}\right.$ and $\left.\mathrm{Pb}\right), 0.83\left({ }^{232} \mathrm{Th}\right.$ and $\mathrm{Pb}), 0.98$ (ambient dose equivalent rate and ${ }^{226} \mathrm{Ra}$ ), 0.91 (ambient dose equivalent rate and ${ }^{232} \mathrm{Th}$ ), and $0.91\left(\mathrm{Cu}\right.$ and $\mathrm{Pb}$ ). The strong correlation between ${ }^{226} \mathrm{Ra},{ }^{232} \mathrm{Th}$, and $\mathrm{Pb}$ is due to the decay processes of the two radionuclides into $\mathrm{Pb}$ isotopes/elements, such as ${ }^{214} \mathrm{~Pb},{ }^{212} \mathrm{~Pb},{ }^{210} \mathrm{~Pb},{ }^{208} \mathrm{~Pb}$, and ${ }^{206} \mathrm{~Pb}$. The $\mathrm{Pb}$ isotope is a decay chain product of uranium (the parent of ${ }^{226} \mathrm{Ra}$ ) and thorium. ${ }^{214} \mathrm{~Pb}$ is a radioactive element and has a half-life of $26.8 \mathrm{~min},{ }^{210} \mathrm{~Pb}$ has a half-life of 22.3 years, and ${ }^{206} \mathrm{~Pb}$ is the stable isotope (the end product of the uranium decay chain). As for thorium decay, ${ }^{212} \mathrm{~Pb}$ is a radioactive element with a half-life of $10.6 \mathrm{~h}$, and ${ }^{208} \mathrm{~Pb}$ is stable, which is the end product of the thorium decay chain $[11,19,34,45,46]$. All the $\mathrm{Pb}$ isotopes have identical chemical properties and toxicity. In addition, the $\mathrm{Pb}$ radioisotope (unstable $\mathrm{Pb}$ isotope) has tremendous potential for toxicity because it emits beta radiation. ${ }^{214} \mathrm{~Pb}$ will decay to ${ }^{214} \mathrm{Bi},{ }^{212} \mathrm{~Pb}$ will decay to ${ }^{212} \mathrm{Bi}$, and ${ }^{210} \mathrm{~Pb}$ will decay to ${ }^{210} \mathrm{Bi}$. Beta radiation will be hazardous if it enters the human body, either from breathing or digestion [34].

Meanwhile, moderate and even negative correlation coefficients were found between radionuclides and some heavy metals $(\mathrm{Cr}, \mathrm{Cd}, \mathrm{Ni}$, and $\mathrm{Zn})$. The relationship between ${ }^{40} \mathrm{~K}$ and the ambient dose equivalent rate was a negative correlation. This negative correlation occurs because the ${ }^{226} \mathrm{Ra}$ and ${ }^{232} \mathrm{Th}$ contents are high, so the $\mathrm{K}$ concentration is not significant.

Lead occurs naturally in the environment. However, anthropogenic activities, such as mining and burning fossil fuels, including transportation, contribute to the release of high concentrations of $\mathrm{Pb}$ to the environment. However, there are no mining and industrial activities in Mamuju. The higher correlation coefficient for these elements is due to the fact that the main source of these metals in this area might be due to the parent rock or soil (i.e., a geogenic source) and burning of fossil fuels. Regarding the geogenic sources, the previous study reported rock types in the Mamuju area are classified into alkaline basalt groups, such as gummite $(>70 \% \mathrm{Th})$, davidite $(15 \% \mathrm{Fe})$, thorianite $(12 \% \mathrm{~Pb})$, and autunite (>48\% U) [20]. 


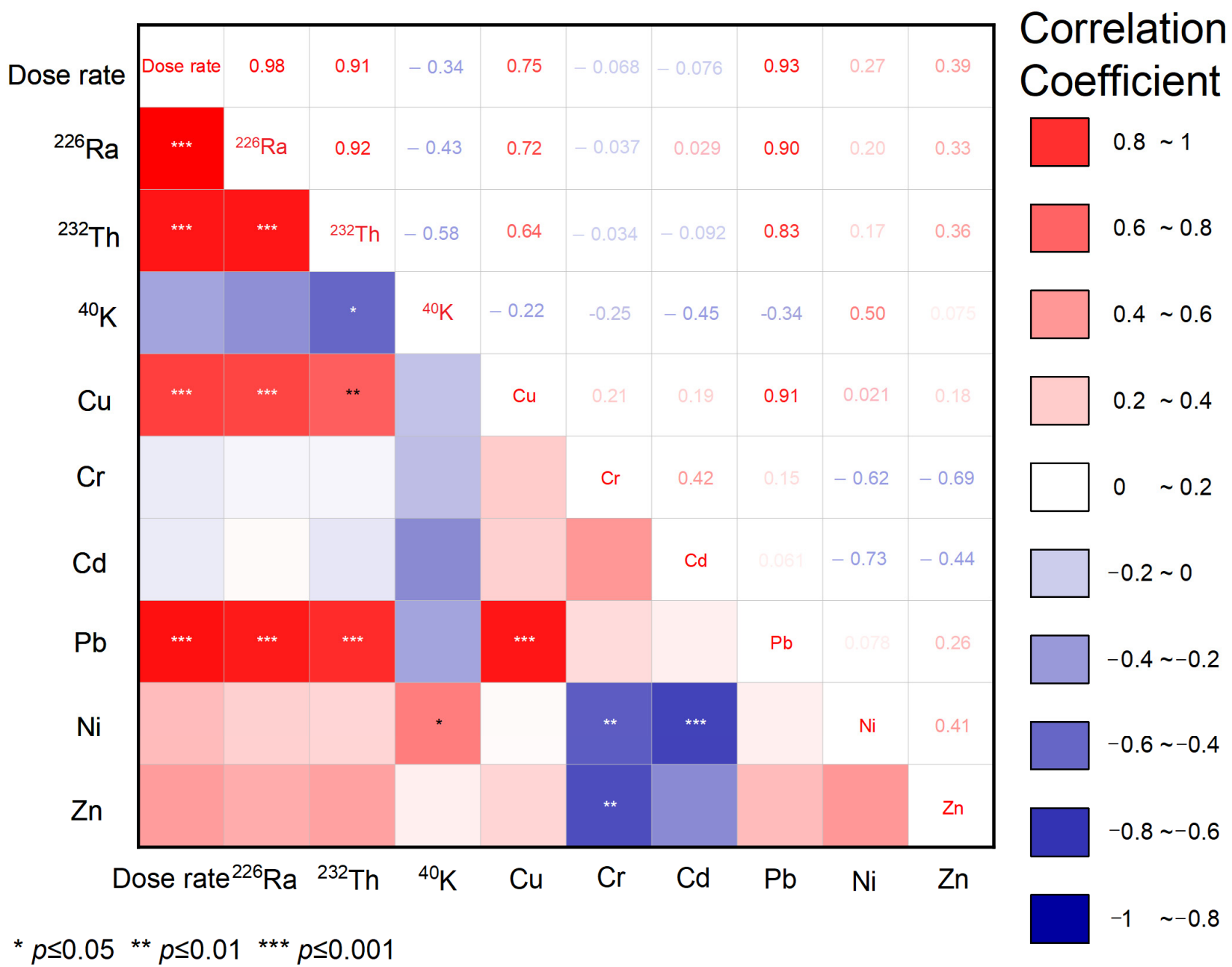

Figure 2. Correlation coefficients between radionuclides and ambient dose equivalent rates (dose rate) and heavy metals.

\section{Conclusions}

Mamuju is a unique area because it is highly naturally radioactive and has a high concentration of heavy metals. The heavy metal concentrations in the soil decrease in the sequence $\mathrm{Zn}>\mathrm{Pb}>\mathrm{Cr}>\mathrm{Cu}>\mathrm{Ni}>\mathrm{Cd}$. A strong positive correlation was found between ${ }^{226} \mathrm{Ra},{ }^{232} \mathrm{Th}$, and $\mathrm{Pb}$. The strong correlation between ${ }^{226} \mathrm{Ra},{ }^{232} \mathrm{Th}$, and $\mathrm{Pb}$ is due to the decay processes of the two radionuclides into $\mathrm{Pb}$ isotopes/elements, such as ${ }^{214} \mathrm{~Pb},{ }^{212} \mathrm{~Pb}$, ${ }^{210} \mathrm{~Pb},{ }^{208} \mathrm{~Pb}$, and ${ }^{206} \mathrm{~Pb}$. The $\mathrm{Pb}$ isotope is a decay chain product of uranium (the parent of ${ }^{226} \mathrm{Ra}$ ) and thorium. The ecological risk index (RI) and cumulative pollution index (IPI) values in Mamuju are 2.05 and 125, respectively, and are therefore within the moderately contaminated category. Lead concentrations in the Mamuju soil samples exceeded the thresholds for heavy metals in soil set by the World Health Organization (WHO), the Indonesian Ministry of Environment, and the United States of America Environmental Protection Agency (US EPA). Moreover, $\mathrm{Pb}$ concentration in the Mamuju soil samples ranged from 109 to $744 \mathrm{mg} \mathrm{kg}^{-1}$, exceeding the worldwide average of $27 \mathrm{mg} \mathrm{kg}^{-1}$. It is possible that these factors might cause negative health effects among the residents of the area.

The determination of the heavy metal in a soil sample is a fundamental study to the identification, monitoring, and assessment of potential sources of pollution in the area. This study is expected to assist local governments, central government, and various stakeholders in making policies regarding environmental safety and population health. This study did not conduct heavy metal measurements in foodstuffs and drinking water. Therefore, we 
suggest that it is necessary to carry out continuous research, especially the measurement of heavy metals in food, water, and humans (bioassays), to obtain more comprehensive data. With these facts, Mamuju can be a prospective area for epidemiological studies to be carried out for both low-dose-rate radiation and heavy metal radiation.

Author Contributions: Conceptualization, E.D.N., S.T. and J.M.; methodology, E.D.N., N.A. and J.M.; validation, J.M. and E.D.N.; formal analysis, E.D.N.; investigation, J.M., M., W., H.A. and E.D.N.; resources, J.M. and S.T.; data curation, E.D.N., H.T., C.K. and J.M.; writing-original draft preparation, E.D.N.; writing-review and editing, E.D.N., J.M., W., C.K., M., H.T., H.A., N.A., M.H. and S.T.; visualization, E.D.N.; supervision, J.M., M.H. and S.T.; funding acquisition, J.M., M.H. and S.T. All authors have read and agreed to the published version of the manuscript.

Funding: This work was partially supported by the Japan Society for the Promotion of Science (JSPS) KAKENHI Grant No. JP16K15368, JP16H02667, JP18KK0261, JP18K10023, JP20H00556, the Hirosaki University Institutional Research Grant, and Indonesia government research grant (DIPA).

Institutional Review Board Statement: Not applicable.

Informed Consent Statement: Not applicable.

Data Availability Statement: Data set available on request to corresponding authors.

Conflicts of Interest: The authors declare no conflict of interest.

\section{References}

1. Stevanović, V.; Gulan, L.; Milenković, B.; Valjarević, A.; Zeremski, T.; Penjišević, I. Environmental risk assessment of radioactivity and heavy metals in soil of Toplica region, South Serbia. Environ. Geochem. Health 2018, 40, 2101-2118. [CrossRef] [PubMed]

2. Nugraha, E.D.; Hosoda, M.; Mellawati, J.; Untara, U.; Rosianna, I.; Tamakuma, Y.; Modibo, O.B.; Kranrod, C.; Kusdiana, K.; Tokonami, S. Radon activity concentrations in natural hot spring water: Dose assessment and health perspective. Int. J. Environ. Res. Public Health 2021, 18, 920. [CrossRef] [PubMed]

3. Singh Sidhu, G.P. Heavy Metal Toxicity in Soils: Sources, Remediation Technologies and Challenges. Adv. Plants Agric. Res. 2016, 5, 445-446. [CrossRef]

4. Shibini Mol, P.A.; Sujatha, C.H. Distribution and geochemical speciation of sediment bound heavy metals in the specific zones of central Kerala, India. Environ. Nanotechnol. Monit. Manag. 2020, 14, 100358. [CrossRef]

5. Balali-Mood, M.; Naseri, K.; Tahergorabi, Z.; Khazdair, M.R.; Sadeghi, M. Toxic Mechanisms of Five Heavy Metals: Mercury, Lead, Chromium, Cadmium, and Arsenic. Front. Pharmacol. 2021, 12, 643972. [CrossRef] [PubMed]

6. Rama Jyothi, N. Heavy metal sources and their effects on human health. In Heavy Metals-Their Environmental Impacts and Mitigation; IntechOpen: London, UK, 2021.

7. Cempel, M.G.N. Nickel: A Review of Its Sources and Environmental Toxicology. Pol. J. Environ. Stud. 2006, 15, 375-382.

8. Megateli, S.; Semsari, S.; Couderchet, M. Toxicity and removal of heavy metals (cadmium, copper, and zinc) by Lemna gibba. Ecotoxicol. Environ. Saf. 2009, 72, 1774-1780. [CrossRef]

9. Corcho Alvarado, J.A.; Balsiger, B.; Röllin, S.; Jakob, A.; Burger, M. Radioactive and chemical contamination of the water resources in the former uranium mining and milling sites of Mailuu Suu (Kyrgyzstan). J. Environ. Radioact. 2014, 138, 1-10. [CrossRef]

10. Neiva, A.M.R.; Antunes, I.M.H.R.; Carvalho, P.C.S.; Santos, A.C.T. Uranium and arsenic contamination in the former Mondego Sul uranium mine area, Central Portugal. J. Geochem. Explor. 2016, 162, 1-15. [CrossRef]

11. Nugraha, E.D.; Wahyudi, K.; Iskandar, D. Radon concentrations in dwelling of south kalimantan, Indonesia. Radiat. Prot. Dosim. 2019, 184, 463-465. [CrossRef]

12. Monged, M.H.E.; Hassan, H.B.; El-Sayed, S.A. Spatial Distribution and Ecological Risk Assessment of Natural Radionuclides and Trace Elements in Agricultural Soil of Northeastern Nile Valley, Egypt. Water Air Soil Pollut. 2020, 231, 338. [CrossRef]

13. Nugraha, E.D.; Hosoda, M.; Kusdiana; Untara; Mellawati, J.; Nurokhim; Tamakuma, Y.; Ikram, A.; Syaifudin, M.; Yamada, R.; et al. Comprehensive exposure assessments from the viewpoint of health in a unique high natural background radiation area, Mamuju, Indonesia. Sci. Rep. 2021, 11, 14578. [CrossRef]

14. Nugraha, E.D.; Hosoda, M.; Tamakuma, Y.; Kranrod, C.; Mellawati, J.; Akata, N.; Tokonami, S. A unique high natural background radiation area in Indonesia: A brief review from the viewpoint of dose assessments. J. Radioanal. Nucl. Chem. 2021, 330, 1437-1444. [CrossRef]

15. Hosoda, M.; Nugraha, E.D.; Akata, N.; Yamada, R.; Tamakuma, Y.; Sasaki, M.; Kelleher, K.; Yoshinaga, S.; Suzuki, T.; Rattanapongs, C.P.; et al. A unique high natural background radiation area-Dose assessment and perspectives. Sci. Total Environ. 2021, 750, 142346. [CrossRef]

16. Nugraha, E.D.; Hosoda, M.; Winarni, I.D.; Prihantoro, A.; Suzuki, T.; Tamakuma, Y.; Akata, N.; Tokonami, S. Dose Assessment of Radium-226 in Drinking Water from Mamuju a High Background Radiation Area of Indonesia. Radiat. Environ. Med. 2020, 9, 79-83. 
17. Sukadana, I.G.; Harijoko, A.; Setijadji, L.D. Tectonic Setting of Adang Volcanic Complex in Mamuju Region, West Sulawesi Province. Eksplorium 2015, 36, 31-44. [CrossRef]

18. Mu'awanah, F.R.; Priadi, B.; Widodo, W.; Sukadana, I.G.; Andriansyah, R. Mobilitas Uranium pada Endapan Sedimen Sungai Aktif di Daerah Mamuju, Sulawesi Barat. Eksplorium 2019, 39, 95. [CrossRef]

19. Rosianna, I.; Nugraha, E.D.; Syaeful, H.; Putra, S.; Hosoda, M.; Akata, N.; Tokonami, S. Natural radioactivity of laterite and volcanic rock sample for radioactive mineral exploration in mamuju, indonesia. Geosci. 2020, 10, 376. [CrossRef]

20. Sukadana, I.G.; Syaeful, H.; Indrastomo, F.D.; Widana, K.S.; Rakhma, E. Identification of Mineralization Type and Specific Radioactive Minerals in Mamuju, West Sulawesi. J. East China Univ. Technol. 2016, 39, 39-48.

21. Saputra, M.A.; Nugraha, E.D.; Purwanti, T.; Arifianto, R.; Laksmana, R.I.; Hutabarat, R.P.; Hosoda, M.; Tokonami, S. Exposures from radon, thoron, and thoron progeny in high background radiation area in Takandeang, Mamuju, Indonesia. Nukleonika 2020 65, 89-94. [CrossRef]

22. BPS. Mamuju Regency in Figures 2018; BPS: Mamuju, Indonesia, 2019.

23. Seklaoui, M.; Boutaleb, A.; Benali, H.; Alligui, F.; Prochaska, W. Environmental assessment of mining industry solid pollution in the mercurial district of Azzaba, northeast Algeria. Environ. Monit. Assess. 2016, 188, 621. [CrossRef] [PubMed]

24. Loredo, J.; Ordóñez, A.; Álvarez, R. Environmental impact of toxic metals and metalloids from the Muñón Cimero mercury-mining area (Asturias, Spain). J. Hazard. Mater. 2006, 136, 455-467. [CrossRef]

25. Gilmore, G.L. Practical gamma-ray spectrometry. In Practical Gamma-ray Spectrometry; John Willey \& Sons, LTD: Warrington, UK, 2008.

26. Muller, G. Index of geoaccumulation in sediments of the Rhine River. GeoJournal 1969, 2, 108-118.

27. Taylor, S.R.; McLennan, S.M. The geochemical evolution of the continental crust. Rev. Geophys. 1995, 33, 241. [CrossRef]

28. Reimann, C.; de Caritat, P. Chemical Elements in the Environment; Springer: Berlin/Heidelberg, Germany, 1998; ISBN 978-3-642-72018-5.

29. Zhiyuan, W.; Dengfeng, W.; Huiping, Z.; Zhiping, Q. Assessment of Soil Heavy Metal Pollution with Principal Component Analysis and Geoaccumulation Index. Procedia Environ. Sci. 2011, 10, 1946-1952. [CrossRef]

30. Arab, L.H.; Boutaleb, A.; Berdous, D. Environmental assessment of heavy metal pollution in the polymetallic district of Kef Oum Teboul (El Kala, Northeast Algeria). Environ. Earth Sci. 2021, 80, 277. [CrossRef]

31. Hakanson, L. An ecological risk index for aquatic pollution control.a sedimentological approach. Water Res. 1980, 14, 975-1001. [CrossRef]

32. Liu, J.; Zhuo, Z.-X.; Sun, S. Concentrations of Heavy Metals in Six Municipal Sludges from Guangzhou and Their Potential Ecological Risk Assessment for Agricultural Land Use. Pol. J. Environ. Stud. 2015, 24, 165-174. [CrossRef]

33. Al-Taani, A.A.; Nazzal, Y.; Howari, F.M.; Iqbal, J.; Bou Orm, N.; Xavier, C.M.; Bărbulescu, A.; Sharma, M.; Dumitriu, C.-S. Contamination Assessment of Heavy Metals in Agricultural Soil, in the Liwa Area (UAE). Toxics 2021, 9, 53. [CrossRef]

34. UNSCEAR. 2008 Report to the General Assembly: Annex B Exposures of the Public and Workers from Various Sources of Radiation; UNSCEAR: Vienna, Austria, 2010; Volume 1, ISBN 978-92-1-142274-0.

35. Nurokhim; Kusdiana; Pudjadi, E. Assessment of natural radioactivity levels in soil sample from Botteng Utara Village, Mamuju Regency Indonesia. J. Phys. Conf. Ser. 2020, 1436. [CrossRef]

36. Shilfa, S.N.; Jumpeno, B.Y.E.B.; Nurokhim. Kusdiana Ambient dose measurement from high natural background radiation (HNBR) in Botteng Utara Village, Mamuju-Indonesia. J. Phys. Conf. Ser. 2020, 1436, 012027. [CrossRef]

37. Kinuthia, G.K.; Ngure, V.; Beti, D.; Lugalia, R.; Wangila, A.; Kamau, L. Levels of heavy metals in wastewater and soil samples from open drainage channels in Nairobi, Kenya: Community health implication. Sci. Rep. 2020, 10, 8434. [CrossRef] [PubMed]

38. Santoso, S.; Haumahu, J.P.; Habi, M.L. Analisis spasial pencemaran logam berat sebagai dampak tempat pembuangan akhir sampah kota ambon pada das wai yori di negeri passo. Budayawan Pertan. 2016, 12, 55-65.

39. Ministry of State for Population and Environment Republic of Indonesia; Canada, D.U. Environmental Management in Indonesia. Report on Soil Quality Standards for Indonesia; Indonesian Government: Jakarta, Indonesia, 1992.

40. Abadin, H.; Ashizawa, A.; Stevens, Y.W.; Llados, F.; Diamond, G.; Sage, G.; Citra, M.; Quinones, A.; Bosch, S.J.; Swarts, S Toxicological Profile for Lead (Updated); Agency for Toxic Substances and Disease Registry: Atlanta, GA, USA, 2020.

41. World Health Organization. Lead Poisoning and Health. Available online: https://www.who.int/news-room/fact-sheets/ detail/lead-poisoning-and-health (accessed on 26 August 2021).

42. Haribala; Hu, B.; Wang, C.; Gerilemandahu; Xu, X.; Zhang, S.; Bao, S.; Li, Y. Assessment of radioactive materials and heavy metals in the surface soil around uranium mining area of Tongliao, China. Ecotoxicol. Environ. Saf. 2016, 130, 185-192. [CrossRef] [PubMed]

43. Bai, H.; Hu, B.; Wang, C.; Bao, S.; Sai, G.; Xu, X.; Zhang, S.; Li, Y. Assessment of Radioactive Materials and Heavy Metals in the Surface Soil around the Bayanwula Prospective Uranium Mining Area in China. Int. J. Environ. Res. Public Health 2017, 14, 300. [CrossRef] [PubMed]

44. Yakovlev, E.Y.; Zykova, E.N.; Zykov, S.B.; Malkov, A.V.; Bazhenov, A.V. Heavy metals and radionuclides distribution and environmental risk assessment in soils of the Severodvinsk industrial district, NW Russia. Environ. Earth Sci. 2020, 79, 218. [CrossRef] 
45. Tokonami, S. Characteristics of Thoron (220Rn) and Its Progeny in the Indoor Environment. Int. J. Environ. Res. Public Health 2020, 17, 8769. [CrossRef] [PubMed]

46. Hosoda, M.; Ishikawa, T.; Sorimachi, A.; Tokonami, S.; Uchida, S. Development and application of a continuous measurement system for radon exhalation rate. Rev. Sci. Instrum. 2011, 82, 015101. [CrossRef] 